\title{
Um "templo de luz": Frente Negra Brasileira (1931-1937) e a questão da educação
}

Petrônio Domingues

Universidade Federal de Sergipe, Departamento de História
A Frente Negra Brasileira é um templo! Templo de luz, porque é uma vasta escola onde nosso espírito se elucida, se esclarece e adquirimos os ensinamentos necessários para vencermos os árduos embates da luta da vida. (Benedito Vaz Costa, 1937, p. 1)

As primeiras décadas depois da abolição da escravatura, em 1888, e a proclamação da República, em 1889, foram decisivas para o futuro da população negra no Brasil. É verdade que a maioria esmagadora dos cativos já havia conquistado sua liberdade no momento da decretação da Lei Áurea. Nesse sentido, a medida foi o reconhecimento legal de algo que já existia de fato. Mas nem por isso seu valor real e simbólico deve ser menosprezado. Como registra George Reid Andrews, observadores contemporâneos e subseqüentes reconheceram que a Abolição representou “uma vitória do povo e - poderíamos acrescentar - uma conquista dos negros livres e escravos" (Andrews, 1991, p. 30). Talvez tenha sido uma das primeiras expressões de democracia da história do país.

O que significava ser livre para a população afrodescendente em diáspora no Brasil? Ter autodeterminação; ser dona de seu próprio destino. E ser cidadão, em um contexto no qual vicejavam os ideários do racismo científico (como darwinismo social, determinismo evolucionista, arianismo, eugenia) e as teorias do branqueamento da nação? Em comum, esses ideários "propalavam a inferioridade dos não-brancos através da subordinação da cultura e da civilização a princípios biológicos" (Seyferth, 2002, p. 15). ${ }^{1}$ Muitos intelectuais atribuíam a inferioridade do povo brasileiro à herança biológica e cultural da "raça negra" impressa no fenômeno da mestiçagem. No entanto, esses pressupostos racistas não ficaram confinados aos meios acadêmicos, tendo sido divulgados por jornalistas através da imprensa, incorporados nos postulados e discursos médicos e debatidos por políticos, que, aliás, os adotaram na elaboração e implementação de programas governamentais (Dávila, 2006).

Para a população negra, nesse contexto deveras adverso, ser cidadão significava ter direitos iguais - e

\footnotetext{
${ }^{1}$ Sobre a recepção e reelaboração das teorias do racismo
} científico e do branqueamento no Brasil do final do século XIX e das primeiras décadas do século XX, ver também Skidmore (1976), Schwarcz (1995) e Hofbauer (2006). 
não ser vista como inferior. Porém, diante da inclusão marginal e das práticas de discriminação racial e tratamento diferenciado em relação à população branca, a cidadania plena continuava sendo um sonho. ${ }^{2}$ Para transformá-lo em realidade, um grupo das "pessoas de cor" logo percebeu que era necessário unir-se e lutar coletivamente, por meio de reivindicações e projetos, pela conquista de respeito, reconhecimento, dignidade, empoderamento, participação política, emprego, educação, terra. Dessas bandeiras de luta, uma das prioritárias foi a da defesa da educação. Afinal, o analfabetismo era um dos principais problemas que assolavam a "raça negra". Em 1918, o jornal O Alfinete revelava que o analfabetismo "predominava em mais de dois terços de tão infeliz raça" (O Alfinete, 22 set. 1918, p. 1). ${ }^{3}$

Para alterar esse quadro, os jornais da imprensa negra paulista instavam a "população de cor" a procurar o caminho da educação formal. Mas não eram apenas os jornais. As associações negras que floresceram nas primeiras décadas do século XX vislumbravam,

${ }^{2}$ Nascido no período da escravidão, Horácio da Cunha reclamava da situação de restrições de direitos na qual a população negra ficou submetida na década de 1930: "Quando foi proclamada a República em 1889, diziam muitos deputados que era preciso dar instrução e educação aos filhos dos ex-escravos que tanto lutaram para esta gloriosa terra. Esses discursos entusiásticos com palavras de liberdade, igualdade, não passaram de utopia para nós pretos" (A Voz da Raça, ago. 1937, p. 2). As reclamações de Horácio da Cunha são de certa forma confirmadas pela historiografia brasileira mais recente. Por exemplo, ao enfocar o mundo rural do Sudeste brasileiro no período imediatamente posterior à abolição da escravatura, Hebe Maria de Mattos de Castro inferiu que o "liberto" era tratado pelos "ex-senhores" como cidadão de "segunda classe", numa condição inferior ao do "homem livre pobre" (Castro, 1995, p. 135).

${ }^{3}$ Em São Paulo, o quadro mais geral de desigualdades raciais se reproduzia na arena educacional. Neusa Maria Mendes de Gusmão observa que existia "um sistema que, privilegiando o branco, fazia da realidade do negro um grande desafio. Entre eles, o ter que educar-se para superar as marcas e os estigmas de seu passado como escravo ou dele descendente" (Gusmão, 1997, p. 55). na educação, senão a solução, pelos menos um prérequisito indispensável para a resolução dos problemas da "gente de cor" na sociedade brasileira. Se a Abolição não resolveu muitas das necessidades sociais, políticas, econômicas e culturais do negro, ela the abriu a possibilidade de organizar-se em condições diferentes daquelas da escravidão, com graus significativamente diferentes de liberdade. "Dada a sua história prévia de vida organizacional", afirma George Andrews, "não surpreende que os afro-brasileiros tenham passado prontamente a reagir a essas novas necessidades e explorar essas novas possibilidades" (Andrews, 1998, p. 218). A educação era concebida por aquelas associações como "uma maneira de o negro ganhar respeitabilidade e reconhecimento, de habilitá-lo para a vida profissional, de permitir-lhe conhecer melhor os seus problemas e, até mesmo, como uma maneira de combater o preconceito" (Pinto, 1993, p. 238).

O conhecimento histórico constrói-se por meio de perguntas. "A formulação de perguntas", afirma Robin George Collingwood, "é o fator dominante na história, assim como em todo trabalho científico. Todo o passo em frente, na argumentação, depende da formulação duma pergunta" (1994, p. 337). A partir desse preceito epistemológico, cumpre elaborar as principais perguntas a serem respondidas neste artigo: de um ponto de vista panorâmico, qual foi a trajetória da Frente Negra Brasileira (FNB), associação que existiu de 1931 a 1937 e mobilizou milhares de negros e negras para lutarem por seus direitos? Do ponto de vista específico, o artigo buscará responder às seguintes questões: como aquela que é considerada a maior (e mais importante) entidade negra do pós-abolição discutiu, problematizou e tratou a questão da educação? Quais foram suas iniciativas no campo educacional? A entidade criou o Departamento de Instrução ou de Cultura. Mas como esse departamento estava estruturado e funcionava? Ele chegou a formular algum projeto político-pedagógico sistematizado? Sabe-se que a FNB criou uma "escola" e alguns cursos, procurando combater o problema do analfabetismo e da deficiência educacional no meio negro, mas como funcionavam essa "escola" e os cursos que eram oferecidos? Eles 
tinham nítido recorte racial? Quem eram os professores? Quais eram os períodos e as séries ofertados? A escola recebia algum tipo de apoio ou subsídio estatal? São essas indagações relacionadas à vida educacional da FNB o foco central da investigação.

\section{As primeiras experiências de escolas para negros depois da abolição}

Já existe um conhecimento acumulado a respeito da implantação, expansão e funcionamento do sistema de ensino na cidade de São Paulo nas primeiras décadas do século XX, mas ainda persistem muitas dúvidas, sendo necessário desvendar novas fontes, discutir novos problemas, adotar novas abordagens e investigar diferentes iniciativas pedagógicas para reconstruir um quadro mais completo das diversas experiências educacionais que ocorreram no período.

É certo que a composição populacional de São Paulo era caracterizada pela diversidade étnica, e o sistema educacional refletia essa situação. Segundo dados do Anuário do Ensino de 1917, havia 565 escolas particulares, das quais 464 eram brasileiras e 101 das colônias de imigrantes (italianas, alemãs, norteamericanas, portuguesas, suíças, francesas e inglesas) (Domingues, 2004, p. 350). Em 1920, era significativa a participação de estrangeiros no universo populacional. Do total de 579.033 habitantes, 205.245 eram estrangeiros. Mas não se pode supor que São Paulo era uma cidade habitada apenas por imigrantes e seus descendentes. Havia também a população nacional, composta de brancos e negros. Apoiando-se em cálculos presumíveis, Florestan Fernandes sustentou que os "negros" e "mulatos" deveriam representar no mínimo $9 \%$ em 1920 e 8,5\% em 1934, o que corresponderia a 52.112 e 90.110 habitantes, respectivamente (Fernandes, 1978, p. 108).

Entre o final do século XIX e as primeiras décadas do XX, a "paulicéia desvairada" foi palco de um processo acelerado de urbanização, industrialização e de um amplo crescimento do setor de serviços. No terreno educacional, a cidade abrigava a expansão da rede de ensino, a qual era formada por diferentes tipos de escolas: pública, particular, leiga, religiosa, profissionalizante, de prendas domésticas. Foi nesse contexto que emergiram escolas para os diversos grupos específicos, dentre as quais aquelas destinadas à "população de cor".

Não há consenso acerca das razões que levaram os negros a criar suas próprias escolas. Uma das hipóteses é que a disputa por um "lugar ao sol” entre os vários grupos étnicos que viviam em São Paulo se operava num clima de tensão. Assim, quando criavam suas próprias escolas, os negros expressariam seu esforço em se organizar, a fim de defender-se naquela disputa (Demartini, 1989, p. 52-53). Outra explicação é que essas escolas foram uma resposta da população negra à discriminação racial que vicejava na rede de ensino. Havia escolas que dificultavam e outras que simplesmente vetavam a matrícula de negros (Domingues, 2004, p. 350). ${ }^{4}$ Em 1929, o jornal Progresso noticiava que o Colégio Sion recusou a matrícula da filha adotiva do "ilustre" ator Procópio Ferreira. Quando sua esposa, a mãe da criança, argumentara que tinha condições financeiras para pagar a mensalidade, a superiora do estabelecimento de ensino teria respondido: "Não é nesse ponto, apenas, que se tornam rigorosos os nossos estatutos. Também não recebemos pessoas de cor, embora oriundas de família de sociedade" (Progresso, 24 mar. 1929, p. 2). Esse episódio demonstra como algumas escolas inscreviam nos estatutos a proibição da matrícula de "pessoas de cor", independentemente de sua classe social. Na mesma edição, o Progresso denunciava o caso em que o dr. José Bento de Assis não pôde matricular sua filha numa escola dirigida por freiras, o College Sacre Coeur, pelo "simples" fato de ela ser negra (idem, p. 5). ${ }^{5}$

As tentativas da população negra de criar escolas após a abolição nem sempre foram exitosas, em virtude de vários fatores: falta de recursos, ausência de apoio

\footnotetext{
${ }^{4}$ A esse respeito, ver também Barros (2005).

${ }^{5}$ Terezinha Bernardo registra outros casos de negros que
} foram discriminados em escolas da rede paulistana de ensino nesse período (1998, p. 68). 
estatal, precária qualificação pedagógica dos gestores dos projetos etc. O resultado é que muitas escolas funcionaram durante pouco tempo. De toda sorte, é importante registrar essas tentativas no estado de São Paulo para entender certos aspectos relacionados à questão da educação na FNB.

Em 18 de maio de 1888, apenas cinco dias após a abolição, foi fundada a Sociedade Beneficente Luís Gama, em Campinas. Com proposta de amparo social, a entidade abriu um "colégio" com cursos para a educação de adultos trabalhadores, no período noturno, e para jovens, no diurno. Depois de muitas dificuldades, o "colégio" encerrou suas atividades na metade da década de 1890 (Maciel, 1997, p. 75).

Em 1902, um professor negro daquela cidade, Francisco José de Oliveira, criou o "colégio" São Benedito para alfabetizar os filhos dos negros e mulatos. Cerca de um ano depois, o jornal $O$ Baluarte informava acerca do curso preparatório, do intermediário e do exame de fim de ano do referido colégio ( $O$ Baluarte, 17 dez. 1903, p. 4). Em 1907, havia 272 alunos matriculados, dos quais 124 eram filhos de imigrantes e 14 nada pagavam. Em 1908, chegou a reunir 422 alunos. Em 30 de abril de 1910, o colégio foi incorporado à Federação Paulista dos Homens de Cor (Domingues, 2004, p. 352).

Outra tentativa de soerguer uma unidade educacional para a população negra de Campinas foi noticiada pelo Almanaque da cidade, de 1908. Fundada pela Irmandade São Benedito em 1898, a escola funcionava em "prédios separados, anexos à capela [do referido] santo". Sua seção masculina possuía 19 alunos matriculados, e o senhor Teodoro Borges como professor; sua seção feminina tinha 21 alunas matriculadas, e a senhora Ana de Almeida Cabral como professora (Pereira, 1999, p. 280-281).

Na cidade de São Paulo houve experiências similares. Baseado em depoimentos de ex-alunos, Argemiro Rodrigues sustenta que a Irmandade de Nossa Senhora do Rosário dos Homens Pretos funcionou desde a época da escravidão como uma escola (Rodrigues, 1987, p. 137-138). Trata-se de uma estimativa de tempo de funcionamento exagerada. De toda sorte, o jornal $O$ Propugnador de 6 de outubro de 1907 informava da continuidade das aulas da escola daquela entidade, nos cursos diurno e noturno. Informava também que o ensino era regular e, diariamente, aumentava o número de matriculados (O Propugnador, apud Pinto, 1993, p. 240).

Determinadas sociedades beneficentes devotavam atenção especial para a formação educacional da população negra. Era o caso da Associação Beneficente Centro da Federação dos Homens de Cor, que abriu uma escola mista chamada São Benedito. Suas atividades eram realizadas na Rua Brigadeiro Galvão, 70-A (O Combate, 13 maio 1915, p. 1). Já a Sociedade Beneficente Amigos da Pátria era a responsável pela escola Progresso e Aurora. Aberta no dia 13 de maio de 1908, era dirigida por Salvador Luís de Paula, um negro ex-ativista do movimento abolicionista. Em 1919, a Progresso e Aurora também abriu classes mistas, uma raridade para a época. Essa foi a escola de negros de maior longevidade na cidade de São Paulo. O jornal Progresso estimava que ela tenha atendido "mil e tantas pessoas" durante todo o período de existência. Com dificuldades financeiras, fechou suas portas em 1929 (Progresso, 26 set. 1929, p. 7; O Clarim da Alvorada, 27 out. 1929, p. 3).

A FNB foi resultado do acúmulo de experiência organizativa dos afro-paulistas. De 1897 a 1930, contabilizou-se cerca de 85 associações negras funcionando na cidade de São Paulo, sendo 25 dançantes, 9 beneficentes, 4 cívicas, 14 esportivas, 21 grêmios recreativos, dramáticos e literários, além de 12 cordões carnavalescos (Domingues, 2004, p. 329). Entre as diversas associações que existiram nesse período, o Centro Cívico Palmares (1926-1929) foi uma das mais proeminentes, seja pela proposta de elevação política, moral e cultural, seja pelo grau de mobilização política da comunidade negra.

Outrossim, foi essa associação que desenvolveu uma importante iniciativa educacional: a criação de uma escola com certa estrutura pedagógica. Funcionando na sede da entidade, as aulas ocorriam nos períodos diurno e noturno. Ensinava-se a ler, a escrever e a contar, bem como gramática, geografia, história, aritmética e 
geometria, entre outras disciplinas. Para as mulheres, ensinavam-se prendas domésticas. De acordo com matéria publicada no jornal Progresso, o Centro Cívico Palmares chegou a ter um "curso secundário que contava com um afinado corpo docente preto", de lá saíram alguns alunos que ingressaram nas "escolas superiores do país" (Progresso, 24 mar. 1929, p. 2). Mantendo ainda uma biblioteca e promovendo palestras culturais periodicamente, a entidade refletiu o amadurecimento do incipiente movimento negro em São Paulo, tendo sido o embrião da FNB.

\section{Uma incursão lacônica pela histórica da Frente Negra Brasileira}

Com o golpe de Estado de 3 de outubro de 1930, Getúlio Vargas foi alçado ao poder no Brasil. Abriu-se uma conjuntura de polarização política. As forças políticas mobilizaram-se em duas frentes: a da esquerda e a da direita. Contudo, tanto as organizações políticas de base popular quanto os partidos das elites não incluíam em seus programas a luta a favor da população negra. Abandonados pelo sistema político tradicional e acumulando a experiência de décadas em suas associações, um grupo de "homens de cor" fundou a FNB, no dia 16 de setembro de 1931. Quase um mês depois, em assembléia realizada no salão das Classes Laboriosas, foi lido e aprovado o estatuto, que estabelecia em seu primeiro artigo:

\footnotetext{
Fica fundada nesta cidade de São Paulo, para se irradiar por todo o Brasil, a Frente Negra Brasileira, união política e social da Gente Negra Nacional, para afirmação dos direitos históricos da mesma, em virtude da sua atividade material e moral no passado e para reivindicação de seus direitos sociais e políticos, atuais, na Comunhão Brasileira. ${ }^{6}$
}

A receptividade da população de ascendência

${ }^{6}$ Uma razoável bibliografia já se ocupou da FNB. Ver Bastide e Fernandes (1959); Mitchell (1977); Fernandes (1978); Moura (1980); Silva (1990); Pinto (1993); Butler (1998); Andrews (1991); Felix (2001); Oliveira (2002); Silva (2003); Domingues (2005). africana foi grande. Em 1936, noticiava-se que a FNB já era formada por mais de "sessenta delegações" (espécie de filiais) distribuídas no interior de São Paulo e em outros estados (A Voz da Raça, set. 1936, p. 1), como Rio de Janeiro, Minas Gerais e Espírito Santo, além de inspirar a criação de entidades homônimas em Pelotas (no Rio Grande do Sul), Salvador e Recife. No seu auge, a entidade contava com milhares de associados. No entanto, os números são bastante contraditórios. Michael Mitchell estimou em 6 mil sócios em São Paulo e 2 mil em Santos (1977, p. 131); Florestan Fernandes avaliou em 200 mil sócios, mas sem especificar se esse número era válido somente para São Paulo (1978, p. 59).

No início, a FNB foi instalada num modesto "escritório" no Palacete Santa Helena, mas como o número de adesões crescia rapidamente, a sede social foi transferida para um casarão da Rua Liberdade, 196 (onde atualmente funciona a Casa de Portugal), na região central de São Paulo. A sede era imensa. No seu interior havia salas da presidência, da secretaria, da tesouraria, de reuniões e dos diversos departamentos. Mantinha-se um salão de beleza, barbeiro, bar, local para jogos, gabinete dentário, um posto de alistamento eleitoral (Pinto, 1993, p. 53). Contava-se ainda com espaço para o funcionamento de uma escola, de cursos profissionalizantes, de um grupo teatral e de um grupo musical, além de um salão para as realizações das festas e cerimônias oficiais.

A organização político-administrativa da FNB era complexa e diversificada. Havia centralização do poder e predominava uma rígida estrutura hierárquica. No decorrer de sua trajetória, a agremiação possuiu dois presidentes. O primeiro foi Arlindo Veiga dos Santos, que ocupou o cargo até pedir afastamento, em junho de 1934. Com sua saída, assumiu a presidência Justiniano Costa, que até aquela época exercia a função de tesoureiro da entidade. No tocante à origem social, a maior parte dos afiliados de base da FNB tinha origem humilde: funcionários públicos, trabalhadores de cargos subalternos e de serviços braçais. Muitos eram subempregados ou simplesmente desempregados. Por sua vez, os cargos de direção eram ocupados geral- 
mente por negros inseridos nos estratos intermediários do sistema ocupacional da cidade e em estado de mobilidade social.

No livro Freedoms given, freedoms won, Kim D. Butler examina o pós-abolição em São Paulo a partir de uma perspectiva comparativa com outros momentos e outras regiões das Américas, a fim de buscar entender padrões de resistência na luta dos descendentes de africanos em diáspora por autodeterminação. Para a historiadora, os afro-paulistanos encontraram nas entidades e jornais negros uma alternativa para pressionar e alcançar a igualdade plena dentro da sociedade dominante. Diferentemente de Salvador, onde existia uma comunidade paralela formada em torno de uma identidade africana, os afro-paulistanos não dispunham de outra solução a não ser lutar pela abertura da sociedade dominante para a sua participação. Nesse sentido, a FNB é vista como expressão de integracionismo alternativo, análogo às opções adotadas pela comunidade negra em Nova York (Butler, 1998, p. 62-68).

George Andrews avalia que a FNB conjugou uma variedade de programas destinados a melhorar a vida do associado e uma mensagem geral de "ascensão moral e progresso material da raça negra". Em virtude da sua capacidade de pressão, conquistou algumas vitórias no campo dos direitos civis. Conseguiu eliminar as políticas de "admissão de somente brancos nos rinques de patinação da cidade e em outros locais de lazer público", bem como levou ao conhecimento de Getúlio Vargas a existência de um veto tácito que impedia o ingresso de negros na Guarda Civil. Sensibilizado, o presidente teria ordenado à corporação que "alistasse imediatamente 200 recrutas negros" (Andrews, 1998, p. 232-234).

Do ponto de vista político, a entidade defendia um projeto nacionalista, de viés autoritário. Arlindo Veiga dos Santos, por exemplo, era radicalmente contrário à democracia e constantemente fazia apologia do fascismo europeu. Semanalmente, em sua sede central, eram realizadas as chamadas domingueiras, nas quais lideranças e intelectuais (negros e brancos) proferiam palestras e certamente transmitiam valores cívicos e ideais políticos. A FNB criou uma série de símbolos identitários (como bandeira, hino, carteira de associado), assim como a Milícia Frentenegrina. Tratava-se de um batalhão paramilitar, composto especialmente por jovens.

As mulheres também foram protagonistas dessa história, assumindo diversas funções na organização. A Cruzada Feminina congregava as negras para empreender trabalhos assistencialistas. Outra comissão feminina, denominada Rosas Negras, organizava bailes e festivais artísticos. Para desenvolver os projetos específicos, a FNB criou vários departamentos: o Jurídico-Social, o Médico (ou de Saúde), o de Imprensa, que era o responsável pela publicação do jornal $A$ Voz da Raça; o de Publicidade (ou de Propaganda), o Dramático (ou Artístico), o Musical, o Esportivo e o de Instrução.

\section{A Frente Negra Brasileira e a questão da educação}

O maior e mais importante departamento da FNB foi o de Instrução, também chamado de Departamento de Cultura ou Intelectual. Era o responsável pela área educacional da FNB. Um de seus motes propagandísticos conclamava: "Eduquemos mais e mais os nossos filhos, dando-lhe uma educação e uma instrução de acordo com as suas aspirações" ( $A$ Voz da Raça, 28 out. 1933, p. 2). O conceito de educação articulado pela entidade era amplo, compreendendo tanto o ensino pedagógico formal quanto a formação cultural e moral do indivíduo. A palavra educação era usada freqüentemente com esses dois sentidos. Já a palavra instrução tinha um sentido mais específico: de alfabetização ou escolarização.

A educação era vista muitas vezes como a principal arma na "cruzada" contra o "preconceito de cor". Os negros deviam estudar, afirmava José Bueno Feliciano, "a fim de não serem insultados a cada momento. Instruídos e educados seremos respeitados; far-nos-emos respeitar" (A Voz da Raça, 24 jun. 1933, p. 4). Acreditava-se que os negros, na medida em que progredissem no campo educacional, 
seriam respeitados, reconhecidos e valorizados pela sociedade mais abrangente. A educação teria o poder de anular o preconceito racial e, em última instância, de erradicá-lo.

A instrução foi uma das questões mais pautadas da FNB: "A instrução bem disseminada na raça será a maior e a mais importante conquista desta entidade" (A Voz da Raça, set. 1936, p. 4). Em quase todas as edições do jornal da FNB encontra-se alusão ao quadro de carência educacional da população negra e à necessidade de ela instruir-se. Geralmente se acreditava que a marginalização do negro no pós-abolição era uma herança da escravidão, que lhe teria entorpecido o potencial intelectual e/ou cultural. Em outros termos, a escravidão teria gerado o despreparo intelectual e/ou cultural do negro para o exercício da plena cidadania no mundo "moderno e civilizado" da República. E tal despreparo só poderia ser revertido pela via da instrução: "o fracasso de nossa gente foi simplesmente porque mostraram-nos a liberdade esquecendo-se de nos abrir a porta que a ela conduz - o livro". Em tom catequético, um articulista do A Voz da Raça asseverava que a "instrução é única e exclusivamente do que se ressente o negro" (A Voz da Raça, 8 jul. 1933, p. 4).

Ela teria o poder de produzir uma "mentalidade nova nas crianças de hoje que serão os moços de amanhã e os velhos do futuro" (A Voz da Raça, mar. 1936, p. 4). Para o frentenegrino que assinava o artigo pelo pseudônimo Rajovia, a "instrução" era o "ponto inicial de uma duradoura melhoria na [...] condição social, intelectual e moral" da "raça" negra ( $A$ Voz da Raça, jan. 1937, p. 1). ${ }^{7}$

Como já foi mencionado, a instrução era concebida como o instrumento mais eficaz para atacar o preconceito. "Instrução", bradava o jornal da FNB, "é o que o negro precisa. O negro deve procurar se libertar dos grilhões da ignorância e quebrar as algemas vergosas do preconceito que o faz aniquilar" (A Voz da Raça, abr. 1936, p. 3). A instrução também seria o principal meio pelo qual o negro adquiriria cultura, que naquela época era entendida como sinônimo de civilidade. João

\footnotetext{
${ }^{7}$ Rajovia era o pseudônimo de Raul Joviano Amaral.
}

de Souza argumentava: "é [n]a arena pedagógica que se acolhe a luta suprema da civilização" ( $A$ Voz da Raça, 2 set. 1933, p. 2). O termo educação também era utilizado algumas vezes como sinônimo de cultura. Nesse sentido, a elevação educacional e/ou cultural proveniente do estudo não seria adquirida apenas num estabelecimento formal de ensino. Conforme dizia uma das lideranças frentenegrinas, "o homem deve estudar até morrer. Não é só nos Grupos Escolares e nos Ginásios, enquanto se é criança ou moço que se forma o intelecto. Em casa, na sociedade, nos clubes, em qualquer parte. [...] Sem estudo não se vence" ( $A$ Voz da Raça, 17 mar. 1934, p. 8).

De qualquer forma, a escola cumpriria um papel estratégico no processo de formação cultural: em um editorial do jornal, ela era considerada "o recinto sagrado onde vamos em comunhão buscar as ciências, artes, música etc. É na escola que encontramos os meios precisos para nos fazer entendidos pelos novos irmãos". O mesmo editorial ainda aconselhava: "Oh pais! Mandai vossos filhos ao templo da instrução intelectual - 'a escola', não os deixeis analfabetos como dantes" (A Voz da Raça, 17 jun. 1933, p. 3). Em vários editoriais e notas escreviam-se prédicas do tipo: "Negros, negros, ide para a escola, aprender, aperfeiçoar no manejo das letras alfabéticas para que possais, amanhã, tirar o melhor partido delas, para a glória do Brasil e de vossa raça oprimida" ( $A$ Voz da Raça, 3 fev. 1934, p. 4). Por sua vez, os professores eram tidos como um baú de sabedoria; "mestres sacerdócios amáveis", os quais dariam a seus "fiéis discípulos [...] a luz do saber" (A Voz da Raça, 17 jun. 1933, p. 3).

A direção do Departamento de Instrução ficava a cargo, a princípio, de José Maria de Assis Pinheiro, que foi substituído, em 1933, por Aristides de Assis Negreiros (A Voz da Raça, 3 jun. 1933, p. 3) e depois por Francisco Lucrécio, que passou a receber o auxílio de Celina Veiga (A Voz da Raça, 17 fev. 1934, p. 4). A primeira iniciativa do departamento foi a criação, em 1932, de um curso de alfabetização de jovens e adultos. Em 1933, anunciava-se o projeto de fundação de uma "instituição escolar" com o nome de "Liceu Palma- 
res", a fim de "ministrar ensino primário, secundário, comercial e ginasial". Notificava-se também que essa "instituição escolar" aceitaria alunos independente de serem ou não sócios da FNB, "assim como brancos, brasileiros ou não" (A Voz da Raça, 25 mar. 1933, p. 4). Apesar do anúncio público, o "Liceu Palmares" não se concretizou. Encontrou-se, outrossim, o comunicado de que, em junho de 1933, teriam "início as aulas do Curso Ginasial e Comercial" ( $A$ Voz da Raça, 3 jun. 1933, p. 3). ${ }^{8}$ O jornal da entidade ainda noticiou a existência do curso secundário, em 1935 ( A Voz da Raça, 31 ago. 1935, p. 1), mas não se tem certeza da validade dessas notícias.

O certo é que o curso de alfabetização funcionava na sede da entidade. Era em princípio destinado a todos os negros ("menores e adultos"), associados ou não à entidade, no período noturno: "Encontra-se em pleno funcionamento na sede da FNB a escola de alfabetização, mantida por aquela entidade, para ministrar instrução aos negros de ambos os sexos" (A Voz da Raça, 25 mar. 1933, p. 2). Com o tempo, pessoas de outros grupos étnico-raciais puderam matricular-se. Ao menos uma fonte atesta essa informação. Em 1937, realizou-se uma "sessão solene", no Teatro Municipal, para comemorar o "900. aniversário do nascimento do grande poeta patrício", Castro Alves. Nela, o escritor modernista Oswaldo de Andrade proferiu um discurso em que dizia:

Hoje, mais do que nunca, um sentido ecumênico se funde nas manifestações públicas. Se aqui vedes pretos e brancos irmanados e solidários, ide à sede de uma das organizações que nos dão este espetáculo - a Frente Negra Brasileira - e vereis como sinal dos tempos, cursando as suas aulas, nacionais brancos, europeus e até japoneses. ( $A$ Voz da Raça, mar. 1937, p. 4)

Isso significa que, ao visitar a escola da FNB, Oswaldo de Andrade encontrou alunos de todas as "cores". Quando a FNB resolveu oferecer o curso

${ }^{8}$ Em 1936, uma nota do jornal comunicava que o "curso ginasial" contava com "primeiro e segundo ano" (A Voz da Raça, maio 1936 , p. 3). de alfabetização para jovens e adultos, buscava-se solucionar um dos principais flagelos que assolavam a população negra: o analfabetismo. O jornal $A \mathrm{Voz} d a$ Raça conclamava que os frentenegrinos se matriculassem no curso. Talvez, em função disso, a procura não era insignificante: "O curso de alfabetização ganha adeptos dia a dia, crescendo assustadoramente. São homens, mulheres e crianças que procuram o manancial da instrução. Os professores são 3 e não dão conta do recado" (A Voz da Raça, 31 mar. 1934, p. 3).

A partir de 1934, a FNB passou a oferecer, além do curso de alfabetização, o curso primário, que inicialmente funcionava no período vespertino, mas que, em um segundo momento, passou a funcionar no período matutino. ${ }^{9}$ Cumpre advertir, entretanto, que há escassos indícios de como se desenvolviam os trabalhos no curso primário; as notícias a respeito dele muitas vezes se confundem com as ações empreendidas no curso de alfabetização para jovens e adultos. Francisco Lucrécio informa que o curso primário estava organizado em três séries distintas, com cada sala de aula correspondendo a uma série. ${ }^{10}$ Marcelino Felix sugere que o curso tinha duração de três anos, adotava um sistema multisseriado, ou seja, várias séries funcionando dentro de uma mesma sala (Felix, 2001), que era mista: meninos e meninas estudavam

${ }^{9}$ Em dezembro de 1934, era noticiado que a "escola" da FNB funcionava "das 12 às 16 e das 19 às 22 horas" ( $A$ Voz da Raça, 15 dez. 1934, p. 1). No entanto, em maio de 1936 uma nota do jornal informava que "Os cursos primários [...], que funcionam sob a direção das professoras: Francisca de Andrade e Dolores Silva, passaram a funcionar das 8 às 12 horas" ( $A$ Voz da Raça, maio 1936, p. 3).

${ }^{10}$ A declaração de Francisco Lucrécio não é totalmente confirmada por outra fonte. Em 1936, uma nota do jornal $A \mathrm{Voz}$ da Raça comunicava que "os cursos primários” da FNB já contavam "com três cursos primários". Francisco Lucrécio se refere a três séries primárias, ao passo que a nota faz alusão a "três cursos primários", que poderiam ser ou não da mesma série. Todavia, é plausível considerar que o autor da nota tenha pretendido utilizar o termo "cursos" como sinônimo de "séries" (A Voz da Raça, maio 1936 , p. 3) 
juntos; fato incomum para a época.

Em sua maioria, os alunos da escola da FNB eram carentes; por isso a associação se esforçava para fornecer gratuitamente o material escolar e o uniforme. Para viabilizar esse fornecimento, era comum promover eventos beneficentes, como os festivais. "No dia 23, no salão das Classes Laboriosas", noticiava o Diário Popular, "a Frente Negra Brasileira realizará grande festival artístico, em que tomarão parte alguns artistas negros já conhecidos em várias platéias do Brasil. [...] Este festival, o primeiro subscrito pelos sócios da Frente, efetuar-se-á em benefício do material escolar do Departamento de Educação frentenegrino" (Diário Popular, 20 abr. 1932, p. 2). Tendo em vista a melhoria de seus projetos educacionais, a FNB criou a Cruzada Feminina em 1935. Conforme foi assinalado alhures, tratava-se de uma comissão feminina que tinha como uma de suas finalidades prover o material didático e o uniforme dos alunos (A Voz da Raça, maio 1936, p. 3). Para arcar com as despesas, a comissão promovia várias campanhas de arrecadação de fundos junto aos associados.

As experiências educacionais da FNB consolidaram-se com as nomeações de professoras por parte do estado. Para lecionar na escola frentenegrina, a então Secretaria de Educação e Saúde do Estado de São Paulo nomeou, a partir de julho de 1934, duas professoras comissionadas: Francisca de Andrade, oriunda do Grupo Escolar de Cabreúva (Diário Oficial do Estado de São Paulo, 18 jul. 1934, p. 6; A Voz da Raça, 11 ago. 1934, p. 2), ${ }^{11}$ e Aracy Ribeiro de Oliveira, proveniente do Grupo Escolar de Boa Esperança (Diário Oficial do Estado de São Paulo, 28 ago. 1937, p. 11; A Voz da Raça, set. 1937, p. 4). Com a nomeação das professoras, a escola passou a ser inspecionada pela referida secretaria. Periodicamente, um inspetor a visitava para acompanhar "o cumprimento das disposições regulares e orientar seus professores, visando a técnica e a finalidade do ensino". Todavia,

11 Ser comissionada permitia que a professora da rede pública fosse nomeada para trabalhar em um estabelecimento de ensino privado e, ainda assim, receber seus vencimentos por parte do Estado.
Pedro Paulo Barbosa lembra que a entidade era alvo de maior controle: "Esse inspetor escolar ia fazer visitas. Numa escola, ele ia uma vez por ano. Agora, na Frente, ia três, quatro vezes por mês". ${ }^{12}$ Malgrado as lembranças desse antigo dirigente frentenegrino, é mister ressaltar que a escola da FNB não tinha seus cursos reconhecidos oficialmente, uma vez que ela era classificada como um estabelecimento de ensino privado. De todo modo, foi a partir da nomeação das professoras que a escola frentenegrina adquiriu nova estrutura. O sistema de avaliação, por exemplo, tornouse mais rigoroso. Foram instituídos os exames finais, com o rendimento dos alunos sendo registrado nos boletins escolares (Felix, 2001).

Parece que apenas o curso primário "contou com professores formados e regularmente remunerados. Os demais cursos eram ministrados por pessoas leigas", as quais se prontificavam a lecionar de maneira voluntária (Pinto, 1993, p. 247). Afora Francisca de Andrade e Aracy Ribeiro de Oliveira, o jornal A Voz da Raça faz alusão a outras professoras: Alcides de Souza, Jersen de Paula Barbosa ( $A$ Voz da Raça, 15 dez. 1934, p. 1) ${ }^{13}$ Dolores Silva (A Voz da Raça, jan. 1937, p. 3) $)^{14}$ e Antonieta Marcondes (A Voz da Raça, nov. 1937 , p. 4). ${ }^{15}$ Todas eram negras.

Em novembro de 1934, o Diário Popular informava em nota que a FNB oferecia o curso "primário e de alfabetização diurno e noturno, dirigidos por

${ }^{12}$ Depoimento de Pedro Paulo Barbosa, concedido a Regina Pahim Pinto em 11 de julho de 1989.

${ }^{13}$ Em 1934, era noticiado que a FNB possuía “cursos diurno e noturno, para menores e adultos", regidos pelas professoras Jersen de Paula Barbosa e Francisca de Andrade..

${ }^{14}$ Em janeiro de 1937, o jornal da FNB comunicava que "esteve em gozo de férias, na cidade de Ribeirão Preto, visitando seus familiares, a snrta. Dolores Silva, professora de uma das classes da Escola Frentenegrina".

${ }^{15}$ Em novembro de 1937, o jornal A Voz da Raça felicitava "a exma. sra. profa. Antonieta Marcondes, uma das dedicadas professoras do curso noturno de alfabetização da FNB", por ter sido "nomeada a 16 do corrente para diretora do Externato Santo André, desta capital". 
professores públicos, nomeados pelo governo" (Diário Popular, 12 nov. 1934, p. 2). ${ }^{16}$ Em 1936, a escola da FNB estava em plena atividade. Ao ser entrevistado pelo jornal A Gazeta, Francisco Lucrécio relatou na ocasião: "Temos na sede central três períodos escolares, funcionando regularmente, ou melhor, otimamente bem" (A Gazeta, 10 maio 1936). Todavia, não há consenso quanto ao número exato de salas de aula, bem como ao de alunos atendidos. As estimativas são presumíveis e desconexas. Lucrécio, em texto memorialístico, aventou que a escola frentenegrina chegou a ter "quatro salas de aula" (Lucrécio, 1989, p. 334; Lucrécio apud Barbosa, 1998, p. 42), sem especificar se destinadas ao curso primário ou ao de alfabetização de jovens e adultos. Já consultando a pesquisa de Marcelino Felix, depreende-se que, até maio de 1936, havia uma sala para o curso primário, no período diurno, e "somente duas salas de alfabetização funcionando", no período noturno (Felix, 2001), o que, por sinal, parece ter sido o mais provável. Em agosto de 1935, o jornal A Voz da Raça comentava que o curso diurno funcionava com a freqüência de "48 crianças mais ou menos"; o noturno, que contaria com grande número de adultos, transcorria "dessa mesma maneira" e o "curso ginasial" era marcado "pela constância geral dos futuros paladinos desta grande raça" (A Voz da Raça, 31 ago. 1935, p. 4). Em agosto de 1936, tem-se referência a "mais de 200 alunos" nas escolas primárias e no curso de formação social ( $A \mathrm{Voz}$ da Raça, ago. 1936, p. 4). Um ano depois, o jornal noticiava a existência de "90 alunos já matriculados" na Escola da Frente Negra Brasileira.

No encerramento do período letivo, promovia-se uma solenidade comemorativa, à qual compareciam os alunos, seus familiares e convidados. No final das aulas de 1934, o jornal O Estado de S. Paulo noticiava: "Encerraram-se solenemente a 30 de novembro as

${ }^{16}$ A partir de 1935, a escola da FNB passou a oferecer "aulas de ginástica aos alunos do curso de alfabetização”. As aulas eram realizadas aos domingos de manhã, no salão de reunião da entidade (A Voz da Raça, 23 nov. 1935, p. 3). aulas dos cursos diurno e noturno patrocinados pela Frente Negra Brasileira [...]. Houve nessa ocasião a apresentação de vários trabalhos executados pelos alunos, como sejam bordados, pinturas, desenhos etc. O sr. Justiniano Costa, [então] presidente geral da Frente Negra, depois de saudar a numerosa assistência, fez a entrega dos boletins de promoção aos alunos" (O Estado de S. Paulo, 4 dez. 1934, p. 9). Já a "festividade" de encerramento do ano letivo de 1935 foi mais apoteótica, contando inclusive com a presença do "nobre" deputado estadual Romeu de Campos Vergal:

Decorreu debaixo de grande entusiasmo o encerramento das aulas do curso de alfabetização da F. N. B. (diurno e noturno). Nas festividades que foram realizadas dia 30 do mês p.p., notava-se a presença de grande número de convidados e famílias dos alunos, do grande Conselho da F. N. B. e do ilustre deputado à Câmara Estadual, dr. Romeu de Campos Vergal. À entrada do grande conselho na sala de aula, os alunos, depois de prolongadas palmas, entoaram o hino nacional. Dado o início à sessão solene, o sr. Presidente Geral, saudou os alunos, incitando-os para no próximo ano esforçarem-se mais ainda em suas lições, correspondendo assim aos elevados préstimos, carinhos e abnegação das esforçadas professoras srtas. Francisca de Andrade e Jersen de Paula Barbosa. Logo após, S. S., o sr. Presidente passou a fazer entrega dos cartões de promoção, o que se passou sob grande entusiasmo por parte dos alunos e da assistência. Em seguida a este ato, o sr. Presidente deu a palavra ao nobre deputado dr. Romeu de Campos Vergal, que em brilhante alocução saudou aos alunos do C. A. F. N. e suas dirigentes, assim como a F. N. B. Terminada esta parte do programa, foram os presentes convidados a passar para o salão de reuniões, onde fora improvisado um palco, sendo apresentado número de declamações e cantos, sendo após levada à cena uma peça de autoria do competente Diretor do Departamento Musical da F. N. B. e dirigente do corpo cênico infantil, prof. Maurício P. Queiroz, sendo os componentes alvos de muitos aplausos [...]. Com este último número deu o sr. Presidente por encerrada a festividade do encerramento das aulas, do ano de 1935, sendo para findar entoado o "Canto da Gente Negra”. (A Voz da Raça, 31 dez. 1935, p. 1 e 4) 
As solenidades de encerramento do ano letivo tinham um significado especial: era o momento em que a FNB conferia visibilidade para o seu trabalho devotado à instrução de crianças, jovens e adultos. Também era uma forma de a entidade despertar nos convidados, familiares dos alunos, enfim, na comunidade negra de modo geral, o interesse pela educação.

Do ponto de vista ideológico, a escola da FNB seguia a orientação nacionalista da entidade; por isso era comum ela comemorar alguns eventos de valor patriótico. Um deles era o da Independência do Brasil, no dia 7 de setembro (A Voz da Raça, ago. 1937, p. 3 ). ${ }^{17}$ Todavia, a maior mobilização da escola ocorria nas celebrações comemorativas do aniversário da entidade, em 16 de setembro. Os alunos eram convocados a participar das celebrações. Em 1936, eles tiveram que visitar o "túmulo dos abolicionistas e frentenegrinos, nas necrópoles da Consolação e Araçá” ( $A$ Voz da Raça, set. 1936, p. 1).

É difícil saber se a escola da FNB atendia ou não às expectativas da clientela. As fontes consultadas não permitem mensurar essa questão de forma judiciosa. De toda sorte, considera-se pertinente registrar o que Placidino Damaceno Motta - um ex-aluno - declarou a respeito, muitos anos depois: "eu praticamente não sabia nada, era mesmo quase analfabeto. Então eu freqüentei a escola noturna da Frente Negra, fiquei bastante satisfeito porque aprendi alguma coisa" (Motta, apud Barbosa, 1998, p. 100).

A FNB também ofereceu um curso de inglês, cujas aulas eram ministradas aos domingos, das 20 às 21 horas, pelo professor Eusébio dos Santos ( $A$ Voz da Raça, jul. 1936, p. 2; jul. 1937, p. 2), e um curso de "Formação Social":

É com grande júbilo que vimos [noticiar] a fundação do Curso de Formação Social. Suas aulas já estão em

${ }^{17}$ Em determinada ocasião, a escola frentenegrina até patrocinou uma excursão com seus alunos ao Museu do Ipiranga, local onde oficialmente foi decretada a independência do Brasil, no dia 7 de setembro de 1822 . funcionamento. Tivemos o feliz ensejo de assistir as aulas do $1^{\circ}$ ano, as de francês, aritmética, geografia, coreografia, contabilidade, história pátria, geral, ciências físicas e naturais, ministradas por professores e auxiliares de conhecida capacidade. Mediante módica contribuição, têm os srs. Frentenegrinos um curso fundamental qual é o ginasial. ( $A$ Voz da Raça, 11 maio 1935, p. 4)

Embora tenha sido noticiado que o curso de "Formação Social" correspondia ao ginasial, tudo indica que ele não era "regular e constava de conferências sobre assuntos da atualidade, política, questões sociais e, principalmente, moral e cívica" (Pinto, 1993, p. 243). Com Arlindo Veiga dos Santos sendo um dos professores, o curso aspirava a garantir o aprimoramento cultural daqueles que o freqüentavam.

Ainda que de maneira embrionária, as lideranças frentenegrinas começaram a desenvolver um posicionamento crítico em face do sistema de ensino, quer no que dizia respeito ao modo como os professores e a escola tratavam os alunos negros, quer em relação aos conteúdos escolares. Olímpio Moreira da Silva denunciava a existência de "grupos escolares" que aceitavam os negros porque eram obrigados, porém seus professores procuravam "menosprezar a dignidade das crianças negras, deixando-as ao lado para que não aprendam e os pais, pobres e desacorsoados pelo pouco desenvolvimento dos filhos, resolvem tirá-los" (A Voz da Raça, 17 fev. 1934, p. 2). Em outro momento, Moreira da Silva voltava a atacar os professores que tratavam os alunos negros de forma diferenciada: "Pois bem, se o indivíduo não está em condições de ensinar o negro, é conveniente que deixe a sua cadeira a outro que o suporte, pois o governo paga aos mestres para ensinar as crianças e não para ensinar as crianças brancas" ( $A$ Voz da Raça, 17 mar. 1934, p. 4). Ao referir-se à história do "filho inteligente" de um "patrício negro", Castelo Alves contava que ele "ia mal amparado pela escola porque a sua professora declarara em plena classe que 'negro com ela não aprende' como se o negro freqüentando uma escola pública pedisse uma escola" ( $A$ Voz da Raça, 6 maio 1933, p. 2). 
Como observa Regina Pahim Pinto, as lideranças frentenegrinas não realizaram críticas sistemáticas (Pinto, 1993, p. 251), mas revelaram que tinham noção, tanto que as escolas da rede oficial de ensino eram pouco receptivas ao alunado negro quanto da postura discriminatória de muitos professores. Outro tipo de crítica dirigia-se aos conteúdos didáticos. $\mathrm{Na}$ opinião de José Bueno Feliciano, "o sentimentalismo envenenado" das escolas, "com as suas referências mais ou menos tolas ao 'pretinho Benedito', com os seus elogios de raposas ao heroísmo de Henrique Dias, têm dado ao negro a impressão de que os seus antepassados foram uns desgraçados e de que os jovens negros só por isso têm de ser sempre uns vencidos". Para alterar essa situação, Bueno Feliciano desafiava os "caluniadores" a "consultar os documentos" históricos (A Voz da Raça, 24 jun. 1933, p. 4). Em diversos momentos, as lideranças frentenegrinas reprovaram a maneira enviesada e/ou preconceituosa com que os autores de livros enfocavam a história do negro e de sua participação na formação do Brasil. Alertavam para as repercussões negativas que tal modelo de história poderia "exercer no aluno negro, ao transmitirem uma imagem de fracasso, uma imagem que contribuía para diminuí-lo e não para elevá-lo, como deveria ser a função da escola" (Pinto, 1993, p. 252).

É interessante notar que a reprovação não ficou somente no plano da denúncia retórica. As lideranças frentenegrinas procuraram esboçar - ainda que por um prisma mítico e esquemático - uma nova abordagem para a história do negro. Alguns fatos da história do Brasil Colônia (como a "heróica" expulsão dos holandeses do Nordeste brasileiro e a "epopéia" do Quilombo dos Palmares) eram freqüentemente rememorados; a intenção era comprovar a participação decisiva do elemento negro no berço da "civilização" brasileira. No período do Império, o episódio mais lembrado era a Guerra do Paraguai. E, para transmitir credibilidade, as lideranças frentenegrinas costumavam apoiar-se nos estudos dos especialistas da matéria:

Assinala o eminente historiador Rocha Pombo - Na Guerra do Paraguai, o mais notável dos nossos conflitos externos, o elemento negro - figurou com mais de dois terços das nossas forças, tanto navais como de terra. Tanto na ordem interna como externa, afirma o inesquecível historiador - o negro tem sido o braço poderoso da nação. ( $A$ Voz da Raça, set. 1936, p. 4)

Por essa perspectiva, a história do Brasil confundia-se com os feitos do negro. Esse foi o "esteio da independência"; o elemento humano central para a implantação da "primeira República". Enfim, a "raça negra" foi a executora dessa "epopéia gigantesca" chamada Brasil (A Voz da Raça, maio 1936, p. 1).

As lideranças frentenegrinas valorizavam a prática da leitura. O livro e a biblioteca eram concebidos como valiosos instrumentos de elevação intelectual e cultural da "população de cor". Com entusiasmo, Rajovia avaliava: "Hoje, admiravelmente se vê desde o menino até ao adulto receber o livro como um pão celestial" ( $A$ Voz da Raça, 8 jul. 1933, p. 2). João B. Mariano recomendava que os "irmãos da raça" seguissem o "caminho sacrossanto do livro". Adiante, ele era mais contundente: "O negro em tempo algum precisou tanto do livro como agora". O livro seria tão importante para o processo de "desenvolvimento moral e intelectual" do negro que João Mariano entendia que, "para a vitória final da raça negra no Brasil, duas coisas são indispensáveis: o livro e a união" (A Voz da Raça, 17 jun. 1933, p. 4). José Bueno Feliciano era mais extremista: "só o livro completará a redenção da Gente Negra do Brasil” ( $A$ Voz da Raça, 24 jun. 1933, p. 4).

Outra iniciativa da FNB no terreno educacional foi a organização de uma biblioteca. Postulava-se que, para triunfar no campo intelectual, o negro teria obrigatoriamente que "desfolhear boas bibliotecas" (A Voz da Raça, 17 jun. 1933, p. 4). Os livros eram adquiridos principalmente por meio de doações dos associados (Felix, 2001). ${ }^{18}$ Em uma delas, Deocleciano Nascimento doou 24 livros, "na maioria, clássicos, nas

${ }^{18}$ Marcelino Felix argumenta que, além das doações, a biblioteca da FNB era mantida com recursos provenientes de rifas beneficentes e do pagamento, por parte dos associados, de uma taxa de manutenção. 
línguas francesa, inglesa e portuguesa" ( $A$ Voz da Raça, 8 abr. 1933, p. 1). ${ }^{19}$ Em outra, João Pedro de Araújo, o bibliotecário da FNB, não só ressaltou a doação que o escritor Rene Tioller fez de sua obra Antônio Bento e a abolição como também a indicou para leitura. Pedro de Araújo julgava que a obra era de "grande interesse para a Raça" e devia ser procurada pelos "frentenegrinos em geral, que ainda desconhecem o que foram os seus avós no passado" ( $A$ Voz da Raça, 18 mar. 1933, p. 4).

${ }^{19}$ Eis a lista dos livros doados por Deocleciano Nascimento: "Estrangeiros: Historie et Philosophie. Mademoiselle de Camargo - Roman; Alice - Roman d'Hier; Lês Trois Duchesses; Le Toisiéme Année de grammaire - por Larive Fleury; Leçons sur les epidemies et léhygiéne publique; A Class Book of english Prose; Bufallo Bill Booder - Storie n. 12 Cleopatra - by H. Rider Haggard; Lights - to - Literature - book three; Nacionais: - Revista Politechnica; Morrer [na] Véspera - romance de Rocha Ferreira; Problemas de Urbanismo - eng. Luiz Aranha; Ação Sumaríssima de Remoção de Tutor - pelo dr. Vicente Giacolini; Gramática Portuguesa, curso primário, $4^{\mathrm{a}}$. Edição - por José Veríssimo; Madeiras do Estado de S. Paulo - por Hauscar Pereira; Formalidades do Júri; São Paulo Médico - órgão científico da classe médica paulista; Homenagem da Sociedade de S. Paulo ao embaixador dr. José Carlos de Macedo Soares, em 26-4-1931, com discurso do homenageado e do dr. A. de Almeida Prado; Triste vida e um pobre soldado; Façanhas do bandido Antonio Silvino e Fiança criminal - pelo dr. Otaviano Vieira”. Um ano depois, a "senhorinha doutora Umbelina Cabral" e o "sr. Osvaldo Martins, ambos ardorosos frentenegrinos", também fizeram uma doação de livros. A relação dos livros era a seguinte. Da “doutora” Umbelina Cabral: "Flor do Lar, A Exilada, A Cascata Rubra, O Lírio da Montanha, Lady Shesburi, Orieto, Marísia, Corações Inimigos de M. Deli. Sonhos de Viagem, A Noite Desce - Henri Ardel; A Semana, Iaiá Garcia - Machado de Assis; Os Três Mosqueteiros, Dama das Camélias - Alexandre Dumas Filho; Amizade Amorosa - Júlio Lemaitre; História de um beijo - Perez Escrich; Elsa e Elena - Gastão Breves; A Marcha - E. Saint Gales; Bodas Negras - Almaquio Diniz; A Indomável, Festa do Trianon - Courts Mahler". Do "sr. Osvaldo Martins": "A Língua Francesa - dr. F. Ahn; História - Pinto e Silva; Coração de Criança - Rila de Barros" (A Voz da Raça, 28 abr. 1934, p. 4).
Em 1937, as professoras da escola da FNB também lançaram uma campanha em prol da fundação de uma "Biblioteca Infantil”. Para levá-la a efeito, foi montada uma comissão para "angariar livros e demais donativos", contando com o apoio dos pais e parentes dos alunos. A expectativa era de que, no início do ano seguinte, a campanha fosse "coroada de êxito", com "ampla e selecionada biblioteca infantil” já em funcionamento (A Voz da Raça, set. 1937, p. 4).

Os dirigentes frentenegrinos ainda cogitaram de formar um centro de estudo, agregando os negros "cultos, os que estudam e os que querem aprender" (A Voz da Raça, jun. 1936, p. 4). Por fim, ventilaram de criar um "Clube dos Intelectuais", para reunir "estudiosos", "poetas, jornalistas ou escritores" negros. Além de espaço de intercâmbio social e cultural, o Clube almejaria garantir a publicação tanto de um jornal literário como de livros dos intelectuais negros (A Voz da Raça, ago. 1937, p. 1).

As atividades educacionais da FNB não ficaram circunscritas à cidade de São Paulo. Várias delegações mantiveram escolas ou cursos de alfabetização. Uma das maiores delegações do interior de São Paulo foi a da cidade de Campinas. Fundada em março de 1932, destacou-se por dedicar uma atenção especial às atividades educacionais. Com alguns meses de funcionamento, a delegação apresentava um nível de organização nada desprezível. Naquela época, encontravam-se em funcionamento "permanente duas escolas e alfabetização, sob a direção dos srs. Odilon Trefiglio e José Himziquer e da senhorinha Ruth Sampaio de Aguiar. Têm matriculados ali 56 alunos de ambos os sexos". Outra professora da "escola" era a "senhorita" Durvalina de Lima. Funcionavam, também, "escolas de corte e culinária, com métodos perfeitos de ensino, a primeira sob a direção da senhorinha Maria José e a outra da senhorinha Ruth Sampaio de Aguiar". Existia um "curso de desenho entregue ao cuidado dos srs. Francisco Xavier Ferreira, Benedito Evangelista e Venancio Barnabé Pompêo". As aulas ocorriam no período noturno. Havia, outrossim, "uma parte esportiva completa, dirigida pelos srs. Alcides Hortencio e Laercio dos Santos. Nesta secção a cul- 
tura física dos frentenegrinos é encarada com especial carinho". "Não só esses úteis departamentos estão ao inteiro dispor dos sócios da Frente Negra", dizia-se, "Cabe destacar que essa organização está aparelhada atendendo em tudo que os pretos careçam e que ao alcance dela esteja. Assim é que existe na sede um livro registro para uso dos seus compatrícios desejosos de qualquer auxílio ou cooperação. Na próxima semana, será instalado com as devidas exigências um gabinete médico, o qual ficará a cargo do dr. Marcondes Cesar, abalizado profissional" (Diário de São Paulo, 31 mar. 1932, p. 8; 15 maio 1932, p. 5; 10 fev. 1933, p. 8; 18 jun. 1933 , p. 10; 20 set. 1933, p. 11; 18 out. 1933, p. $11 ; 7$ nov. 1933 , p. 4).

Outra importante delegação da FNB foi a de Santos. O Diário da Manhã noticiava que a delegação, com menos de um ano de atividade, oferecia cursos de alfabetização; aulas diurnas e noturnas para crianças e adultos sem distinção de "cor", em que se ensinava português, aritmética, geografia, história do Brasil e desenho. A delegação ainda oferecia aulas de "inglês", "espanhol", "alemão", "italiano", "piano" e "violino" (Diário da Manhã, 7 abr. 1932, p. 2). Além das citadas, outras delegações da FNB mantinham "escolas" ou cursos de alfabetização. Esta era a situação das delegações de Sorocaba. ${ }^{20}$ Tietê, Brotas, Itapira, Muzambinho, dentre outras. No caso de Muzambinho, em Minhas Gerais, ocorreu algo excepcional: a "escola primária" da delegação da Frente Negra foi reconhecida oficialmente e municipalizada, em 1937. A solenidade de encampação foi aparatosa, contando inclusive com a presença do prefeito da cidade:

A escola noturna que vinha sendo dirigida pela snrta. Maria Madalena de Jesus, há mais de 3 anos e, ultimamente, a cargo da snrta. Maria Bertolina Silva; foi pelos exmos. snrs. drs. José Januário de Magalhães, m. d. Prefeito Municipal e Jacomino Inacarato, ilustre representante do snr. Inspetor

${ }^{20}$ A sucursal da FNB de Sorocaba mantinha uma escola noturna. Sobre essa questão, ver Silva (2005), especialmente o capítulo 4 .
Escolar, dr. Imael Coimbra, oficializada como Escola Noturna Municipal da Frente N. Brasileira.

Às 8:30 horas da noite do dia 21 do mês p.p. deu-se a abertura das solenidades, falando após a instalação o ilustrado patrício e representante da sede central de Minas - sr. Raimundo Macedo Filho, em agradecimento, pela escolha de seu nome e nomeação para lecionar na referida escola. Falaram o jovem Lázaro Silva, sr. Leopoldo Poli, dr. Jacomino Inacarato e dr. José J. de Magalhães, que brilhantemente proporcionaram maiores alegrias aos frentenegrinos de Muzambinho, pelas recepções e palavras amigas que foram dirigidas. O sr. João Cândido dos Santos - da Sede Central de Minas e Secretário ad-hoc nesta solenidade, discursou eloqüentemente, com nobreza de espírito, bondade de coração, fez votos de prosperidade à recém-instalada Escola. Ao terminar foi cantado o hino da Gente Negra Brasileira, encerrando a sessão. (A Voz da Raça, set. 1937, p. 2)

Pretendendo que as demais entidades negras seguissem seu exemplo, a FNB as convocava, em 1934, a abrir escolas e a investir na formação cultural da população negra (A Voz da Raça, 15 dez. 1934, p. 4). Quase dois anos depois, a convocação era retomada: "É um dever de nossas associações abrir escolas, difundir instrução, semear livro, criar uma nova mentalidade liberta de preconceitos" ( $A$ Voz da Raça, jul. 1936, p. 4).

Independentemente da eficácia dessas convocações, vale assinalar que a FNB não era a única organização do meio negro paulista que mantinha projetos educacionais na década de 1930. O Clube Recreativo 28 de Setembro, da cidade de Jundiaí, por exemplo, mantinha em suas dependências uma escola, chamada "Cruz e Souza" (A Voz da Raça, 15 dez. 1934, p. 2; abr. 1937, p. 2). Por sua vez, o Centro Cívico José do Patrocínio, da cidade de São Carlos, criou "escolas de alfabetização e de instrução profissional". ${ }^{21}$ Nessa

${ }^{21}$ O parágrafo completo da notícia era o seguinte: "Um grupo de abnegados fundou-se em 20 de maio de 1933, uma sociedade cooperativa e de proteção, não só no sentido moral como material, com o intuito de dispensar conforto e desvelo, instrução e assistên- 
mesma cidade, o Grêmio Recreativo Flor de Maio também abriu uma escola, oferecendo cursos que correspondiam ao primeiro ciclo do ensino fundamental (antigo primário). Escarafunchando as atas da agremiação, Márcio Aguiar verificou que o início das aulas estava convocado para o dia primeiro de outubro de 1934. Dois anos depois, uma ata registrava um ofício da Prefeitura, comunicando ao Flor de Maio a nomeação de "um professor para o curso noturno que reiniciaria as aulas após o término das férias" (Aguiar, 1998, p. 55).

Raul Joviano Amaral informava que as iniciativas voltadas para a "instrução" das "Sociedades Beneficentes ou Clubes Instrutivos da gente de cor" funcionavam em condições precárias de instalação, ressentindo-se da falta de "apoio material"; as aulas eram ministradas em "salinhas acanhadas, com bancos toscos e mesas de caixão, isso mesmo custeado por bolsa de particulares". Por essa razão, ele considerava necessário o "auxílio do governo" ( $A$ Voz da Raça, 23 jun. 1934, p. 2).

As organizações de outros estados que se inspiravam na experiência da FNB também se preocupavam com a alfabetização e educação da "população de cor". Esse foi o caso da FNP, do Rio Grande do Sul. Nascida no bojo de uma "Campanha Pró-Educação", a agremiação inscrevia logo no primeiro artigo de seu estatuto que se destinava "a pugnar pela união, educação, instrução, reabilitação e engrandecimento de todos os elementos da raça negra". Para tanto, pretendia realizar palestras, conferências; organizar bibliotecas, cursos de alfabetização, em suma, ações que tendiam a elevar o nível intelectual e cultural do "homem de cor". A instrução era entendida como a

cia social, a todos os negros desamparados desta cidade, mantendo para isso escolas de alfabetização e de instrução profissional, aos sócios e à família dos mesmos, comprometendo-se ainda a trabalhar tanto quanto possível pelo erguimento social dos órfãos e das crianças de pais esquecidos, de tal, encaminhando-os para as escolas e evitando que trilhem o caminho do mal, para fazê-los homens dignos não só da raça como da coletividade social a que pertençam” (A Voz da Raça, 17 mar. 1934, p. 8). principal arma dos negros na conquista da cidadania, pois, uma vez instruídos, eles tomariam conhecimento de seus direitos e deveres, bem como estariam habilitados para advogá-los..$^{22}$ Para algumas de suas lideranças, a FNP devia empregar seus esforços apenas à educação, por isso pleitearam mudar seu nome para Frente Educacional Pelotense (Loner, 1999).

A Frente Negra Baiana também tinha como uma de suas prioridades a atuação no campo educacional. Em sua sede, oferecia cursos de alfabetização no período noturno. Em 1933, os jornais de Salvador noticiavam que a organização estava ampliando suas atividades, abrindo "inscrições para os cursos: primário, complementar, de música, datilografia e línguas" (Diário da Bahia, 21 jun. 1933, apud Bacelar, 1996, p. 76). Sem qualquer tipo de patrocínio, a Frente Negra Baiana promovia festas beneficentes para custear a compra do mobiliário escolar e de todas as demais despesas dos cursos.

À medida que a FNB foi adquirindo maior representatividade no cenário nacional, surgiu a idéia de transformar a organização em partido político. Em 1936, depois de um longo processo de articulação e pressão política, a idéia tornou-se realidade: o Tribunal Superior de Justiça Eleitoral permitiu o registro do Partido da Frente Negra Brasileira. Mas o novo partido não teve oportunidade de demonstrar sua força política e passar pelo teste das urnas: em 10 de novembro de 1937, com o apoio das Forças Armadas, Getúlio Vargas determinou o fechamento do Congresso Nacional e anunciou em cadeia de rádio a outorga de uma nova Constituição da República. A "polaca", como ficou conhecida, foi inspirada nas constituições fascistas da Itália e da Polônia. A partir de sua vigência, ficou praticamente regulamentada a ditadura do Estado Novo: foram suprimidos direitos civis e muitas das liberdades individuais. Em 2 de dezembro de 1937, um

22 Beatriz Ana Loner corrobora essa assertiva: "A Frente Negra Pelotense tinha na educação da raça um de seus objetivos principais, pois a educação era vista como o grande instrumento de valorização social e meio de retirar o negro da situação de miséria e marginalização em que vivia" (1999, p. 7). 
decreto aboliu todos os partidos políticos, declarandoos ilegais. Como consequiência, a FNB encerrou suas atividades, alguns meses antes das comemorações dos cinqüenta anos da abolição, em 1938.

\section{Considerações finais}

A FNB foi expressão da capacidade de união e luta da "população de cor" na década de 1930. Para as lideranças frentenegrinas, a educação era o que hoje se designa bem inviolável. Além da integração e ascensão social do indivíduo na sociedade, ela possibilitaria a eliminação do preconceito e, no limite, garantiria as condições para o exercício da cidadania plena.

Examinando o discurso das lideranças frentenegrinas, percebe-se como elas tinham uma visão crítica em relação à falta de políticas públicas educacionais dirigidas à população negra. Tais lideranças entendiam que a ausência de "instrução" era um dos fatores fundamentais que levava o negro a viver alienado culturalmente, desqualificado profissionalmente, manipulado politicamente, sem perspectiva de progredir socialmente, em síntese, a viver em condições precárias; por isso elas julgavam que o acesso à "instrução" era condição sine qua non para que essa situação fosse revertida. Em outras palavras, o acesso à "instrução" seria um pré-requisito básico para solucionar os problemas do negro na sociedade brasileira.

Amiúde, as lideranças frentenegrinas difundiram a idéia de que a educação era o principal, senão um dos principais instrumentos a permitir que uma pessoa negra vencesse na vida ou, ao menos, obtivesse as mesmas oportunidades sociais, econômicas, políticas e culturais de uma pessoa branca. Assim, é escusado dizer que a FNB sempre defendeu a melhoria no nível educacional e cultural da "população de cor". Já no terceiro parágrafo do estatuto, a agremiação declarava que uma de suas finalidades era a "elevação intelectual, artística, técnica, profissional [...] da Gente Negra" (Diário Oficial do Estado de São Paulo, 4 nov. 1931, p. 12). Porém a FNB não consignou a defesa da "elevação intelectual" apenas no seu estatuto. Ela desenvolveu - ou planejou desenvolver - várias ações concretas de combate às deficiências educacionais e culturais do meio negro, criando curso de alfabetização, de complemento cultural - chamado curso de "Formação Social" - e uma escola que oferecia o equivalente ao primeiro ciclo do ensino fundamental.

A implementação e a manutenção de um projeto escolar exigiram esforço notável por parte da FNB, tendo em vista suas limitações infra-estruturais, pedagógicas e de recursos financeiros. Com a fundação de uma escola, o negro tomou para si a tarefa de educar seus pares. Nesse caso, a FNB revestiu-se da característica de algumas organizações dos movimentos sociais: a execução de projetos que substituem o papel do Estado. Essas organizações passam a oferecer um serviço ou bem que, a rigor, é obrigação do poder público e direito de qualquer cidadão.

A escola da FNB foi fundada no bojo de uma jornada de conscientização e mobilização da "população de cor". Contudo, ela não sistematizou uma proposta de política educacional mais abrangente. Aliás, de forma metódica, ela não forjou um projeto pedagógico centrado na questão do negro nem desenvolveu material didático específico, uma grade curricular alternativa ou se debruçou em torno de uma prática de ensino totalmente inovadora. Mesmo assim, pode-se supor que foi a partir dela que se começou a ventilar algumas idéias de como deveria ser a educação do negro no Brasil. Ainda que de maneira pouco articulada, as lideranças frentenegrinas foram precursoras em tecer críticas quer à dimensão preconceituosa dos conteúdos escolares, quer à forma discriminatória como os professores e os estabelecimentos de ensino se relacionavam com os alunos negros. Mas não se deve cometer anacronismo: a questão de uma pedagogia interétnica e multirracial não estava colocada na década de 1930.

Com efeito, só o fato de uma escola reunir somente professores "de cor" e dezenas ou talvez centenas de crianças, jovens e adultos negros em um único recinto já causava efeito simbólico. Isto é, a escola da FNB favorecia o surgimento de um ambiente étnico de incentivos múltiplos, o que por sua vez deve ter influenciado positivamente na formação da auto-estima 
da maior parte de sua clientela. Quando se agrupavam com seus “irmãos de cor", os alunos negros sentiam-se a cavaleiro e quiçá mais motivados a aproveitar aquele momento de aprendizagem.

A FNB não restringiu as atividades educacionais à sua sede. Várias delegações do interior de São Paulo e de outros estados mantiveram escolas ou cursos de alfabetização. Houve ao menos um caso de delegação da FNB cuja escola foi reconhecida oficialmente. Ela ainda influenciou outras organizações negras a desenvolver projetos de caráter educacional.

As conquistas empreendidas pela FNB no terreno educacional possibilitaram a inserção condigna de alguns negros na sociedade e, ao mesmo tempo, contribuíram para o acúmulo de forças do movimento social que procurou sensibilizar o Estado e a sociedade civil da importância de construção de uma ordem étnico-racial mais justa e igualitária no país. A despeito de todas as dificuldades enfrentadas pela escola frentenegrina, sua experiência histórica constitui um capítulo de resistência da população negra ante sua exclusão (ou inclusão marginal) no sistema de ensino das primeiras décadas do período republicano.

\section{Referências bibliográficas}

AGUIAR, Márcio Mucedula. As organizações negras em São Carlos: política e identidade cultural. Dissertação (Mestrado em Ciências Sociais) - Centro de Educação e Ciências Humanas, Universidade Federal de São Carlos, São Carlos, 1998.

ANDREWS, George Reid. O protesto político negro em São Paulo-1888-1988. Estudos Afro-Asiáticos, Rio de Janeiro, n. 21, p. 27-48, dez. 1991.

Negros e brancos em São Paulo (1888-1988). Trad.

Magda Lopes. Bauru: EDUSC, 1998.

BACELAR, Jeferson. A Frente Negra Brasileira na Bahia. AfroÁsia, Salvador, n. 17, p. 73-85, 996.

BARBOSA, Márcio (Org.). Frente Negra Brasileira: depoimentos. São Paulo: Quilombhoje, 1998.

BARROS, Surya Aaronovich Pombo de. Discutindo a escolarização da população negra em São Paulo entre o final do século XIX e início do XX. In: ROMÃO, Jeruse (Org.). História da educação do negro e outras histórias. Brasília: MEC/SECAD, 2005. p. 79-92.
BASTIDE, Roger; FERNANDES, Florestan. Brancos e negros em São Paulo: ensaio sociológico sobre aspectos de formação, manifestações e efeitos do preconceito de cor na sociedade paulista. 2. ed. São Paulo: Companhia Editora Nacional, 1959. (Brasiliana, v. 305.)

BERNARDO, Terezinha. Memória em branco e negro: olhares sobre São Paulo: EDUC/Editora da UNESP, 1998.

BUTLER, Kim. D. Freedoms given, freedoms won: afro-brazilians in post-abolition. São Paulo/Salvador: New Brunswick Rutgers University Press, 1998.

CASTRO, Hebe Maria Mattos de. Das cores do silêncio: os significados da liberdade no sudeste escravista - Brasil, século XIX. Rio de Janeiro: Arquivo Nacional, 1995.

COLLINGWOOD, Robin George. A idéia de história. Trad. Alberto Freire. 8. ed. Lisboa: Presença, 1994.

DÁVILA, Jerry. Diploma da brancura: política social e racial no Brasil - 1917-1945. Trad. Claudia Sant’Ana Martins. São Paulo: Editora da UNESP, 2006.

DEMARTINI, Zeila de Brito Fabri. A escolarização da população negra na cidade de São Paulo nas primeiras décadas do século. ANDE, Revista da Associação Nacional de Educação São Paulo, v. 8 , n. 14 , p. $51-60,1989$.

DOMINGUES, Petrônio. Uma história não contada: negro, racismo e branqueamento em São Paulo no pós-abolição. São Paulo: SENAC, 2004.

. A insurgência de ébano: a história da Frente Negra Brasileira. Tese (Doutorado em História) - Faculdade de Filosofia, Ciências e Letras, Universidade de São Paulo, São Paulo, 2005.

FELIX, Marcelino. As práticas político-pedagógicas da Frente Negra Brasileira na cidade de São Paulo (1931-1937). Dissertação (Mestrado em Educação) - Faculdade de Educação, Pontifícia Universidade Católica de São Paulo, São Paulo, 2001.

FERNANDES, Floretan. A integração do negro na sociedade de classes. 1. v. 3. ed. São Paulo: Ática, 1978.

GUSMÃO, Neusa Maria Mendes de. Fundo de memória: infância e escola em famílias negras de São Paulo. Cadernos CEDES, Campinas, v. 18, n. 42, p. 53-74, ago. 1997.

HOFBAUER, Andréas. Uma história de branqueamento ou o negro em questão. São Paulo: Editora da UNESP, 2006.

LONER, Beatriz Ana. Negros: organização e luta em Pelotas. História em Revista, Pelotas, v. 5, p. 7-27, dez. 1999.

Classe operária: mobilização e organização em Pelotas (1888-1937). Tese (Doutorado em Sociologia) - Instituto de Filosofia e Ciências Humanas, Universidade Federal do Rio Grande do Sul, Porto Alegre, 1999. 
LUCRÉCIO, Francisco. Memória histórica: a Frente Negra Brasileira. Revista de Cultura Vozes, Petrópolis, v. 83, n. 3, p. 332-342, maio/jun. 1989.

MACIEL, Cleber da Silva. Discriminações raciais: negros em Campinas (1888-1926). 2. ed. Campinas: CMU/UNICAMP, 1997.

MITCHELL, Michael. Racial consciousness and the political attitudes and behavior of blacks in São Paulo, Brazil. 1977. Dissertação (Ph. D. em Ciência Política) - Universidade de Indiana, 1977.

MOURA, Clóvis. Organizações negras. In: SINGER, Paulo; BRANT, Vinicius Caldeira (Orgs.). São Paulo: o povo em movimento. Petrópolis: Vozes, 1980. p. 143-175.

OLIVEIRA, Laiana de Oliveira. A Frente Negra Brasileira: política e questão racial nos anos 1930. Dissertação (Mestrado em História) - Instituto de Filosofia e Ciências Humanas, Universidade do Estado do Rio de Janeiro, Rio de Janeiro, 2002.

PEREIRA, José Galdino. Colégio São Benedito: a escola na construção da cidadania. In: NASCIMENTO, Terezinha Aparecida Quaiotti Ribeiro do et al. Memórias da educação: Campinas (18501960). Campinas: CMU/UNICAMP, 1999. p. 275-312.

PINTO, Regina Pahim. O movimento negro em São Paulo: luta e identidade. Tese (Doutorado em Antropologia) - Faculdade de Filosofia, Letras e Ciências Humanas, Universidade de São Paulo, São Paulo, 1993.

RODRIGUES, Argemiro. Irmandade Nossa Senhora do Rosário dos Homens Pretos. Cadernos de Pesquisa, São Paulo, n. 63, p. 137-138, nov. 1987.

SCHWARCZ, Lilia Moritz. O espetáculo das raças: cientistas, instituições e questão racial no Brasil (1870-1930). São Paulo: Companhia das Letras, 1995.

SEYFERTH, Giralda. Racismo e o ideário da formação do povo no pensamento brasileiro. Cadernos PENESB, n. 4, p. 13-32, 2002.

SILVA, Fatima Aparecida. Escola, movimento negro e memória: o 13 de maio em Sorocaba - 1930. Dissertação (Mestrado em Educação) - Universidade de Sorocaba, Sorocaba, 2005.

SILVA, José Carlos Gomes da. Os suburbanos e a outra face da cidade. Negros em São Paulo: cotidiano, lazer e cidadania (19001930). Dissertação (Mestrado em Ciências Sociais) - Instituto de Filosofia e Ciências Humanas, Universidade Estadual de Campinas, Campinas, 1990.

SILVA, Maria Aparecida Pinto. A Voz da Raça: uma expressão negra no Brasil que queria ser branco. Tese (Doutorado em Ciências
Sociais) - Faculdade de Ciências Sociais, Pontifícia Universidade Católica de São Paulo, São Paulo, 2003.

SKIDMORE, Thomas. Preto no branco: raça e nacionalidade no pensamento brasileiro. Rio de Janeiro: Paz e Terra, 1976.

\section{Fontes primárias}

A Voz da Raça. São Paulo, 20 abr. 1932; 18 mar. 1933; 25 mar. 1933; 6 maio 1933; 3 jun. 1933; 17 jun. 1933; 24 jun. 1933; 8 jul. 1933; 2 set. 1933; 28 out. 1933; 3 fev. 1934; 17 fev. 1934; 17 mar. 1934; 31 mar. 1934; 23 jun. 1934; 11 ago. 1934; 15 dez. 1934; 4 dez. 1934; 11 maio 1935; 31 ago. 1935; 31 dez. 1935; mar. /1936; abr. 1936; maio 1936; jun. 1936; jul. 1936; set. 1936; mar. 1937; abr. 1937; jul. 1937; ago. 1937; set. 1937; nov. 1937.

O Baluarte, Campinas, p. 4, 17 dez. 1903.

O Combate, Campinas, p. 1, 13 maio 1915.

O Clarim da Alvorada, São Paulo, p. 3, 27 out. 1929.

Diário da Bahia, Salvador, 21 jun. 1933.

Diário da Manhã, Santos, 7 abr. 1932.

Diário de São Paulo, São Paulo, 31 mar. 1932; 15 maio 1932; 10 fev. 1933; 18 jun. 1933; 20 set. 1933; 18 out. 1933; 7 nov. 1933. Diário Oficial do Estado de São Paulo, São Paulo, 4 nov. 1931; 18 jul. 1934; 28 ago. 1937.

Progresso, São Paulo, 24 mar. 1929.

Progresso, São Paulo, p. 7, 26 set. 1929.

PETRÔNIO DOMINGUES, doutor em história pela Universidade de São Paulo (USP), é professor do Departamento de História na Universidade Federal de Sergipe (UFS). Publicações recentes: A nova abolição (São Paulo: Selo Negro, 2008); "Movimento negro e educação: alguns subsídios históricos" (In: MARCON, Frank; SOGBOSSI, Hippolyte Birce (Orgs.). Estudos africanos, história e cultura afro-brasileira: olhares sobre a lei 10.639/03. São Cristóvão: Editora UFS, 2007. p. 25-39); Uma história não contada: negro, racismo e branqueamento em São Paulo no pós-abolição (São Paulo: SENAC, 2004). Pesquisa em andamento: “Associação Cultural do Negro (1954-1976): um esboço histórico”.E-mail: pjdomingues@yahoo.com.br

Recebido em novembro de 2007 Aprovado em julho de 2008 
objective of this dissertation which analysed diverse documents on public education is to demonstrate the popular character of the school in the Empire and argument that its failure in the function of educating and civilizing poor, negro and mixed-race children is exactly in the characterization of the clientele at whom the public school was aimed in the XIX century as non-educable. The importance of the theme for deepening the debate on the history of the school in Brazil is also highlighted.

Key words: history of education; imperial education; public school; social class; race

Escuela pública para los negros y los pobres en Brasil: un invento imperial El artículo presenta datos finales de estudios sobre la escolarización de niños pobres, negros y mestizos en Brasil, específicamente en la provincia de Minas Gerais durante la vigencia de la Monarquía constitucional (18241889). Para su desarrollo fueron investigados diferentes documentos de la instrucción pública y la principal tesis es demostrar el carácter popular de la escuela del Imperio y discutir sobre como su fracaso en la función de instruir y civilizar pobres, negros y mestizos puede estar exactamente relacionada con la descalificación de la condición de educabilidad de la clientela a la cual se destinaba la escuela pública del siglo XIX. Destaca también la importancia de la temática para la ampliación de los debates sobre la historia de la escuela en Brasil.

Palabras clave: historia de la educación; educación imperial; escuela pública; clase social; etnia

Petrônio Domingues

\section{Um “templo de luz": Frente Negra Brasileira (1931-1937) e a questão da educação \\ $\mathrm{O}$ artigo examina como a Frente Negra}

Brasileira (1931-1937) - considerada a maior e mais importante organização negra que se projetou no cenário nacional após a abolição da escravatura - discutiu, problematizou e tratou a questão da educação. Verifica-se como as lideranças dessa organização tinham uma visão crítica em relação à falta de políticas públicas voltadas à população negra e concebiam a educação como uma ferramenta estratégica para a inserção desse segmento populacional à sociedade. Além da integração social, a educação possibilitaria a eliminação dos preconceitos e, em última instância, garantiria as condições para o exercício da cidadania plena.

Palavras-chave: negros; relações raciais; educação; multiculturalismo

\section{A "temple of light": the Brazilian} Negro Front (Frente Negra Brasileira) (1931-1937) and the education question

The article analyses how the Brazilian Negro Front (1931-1937) - considered the largest and most important black organization to be projected on the national scene after the abolition of slavery-discussed, questioned and dealt with the issue of education. It can be observed that the leaders of that organization had a critical vision of the lack of public policies for the black population and saw education as a strategic tool for the social integration of this segment of the population. In addition to social integration, education would make possible the elimination of prejudice and, ultimately, would ensure the conditions for the exercise of full citizenship.

Key words: negroes; race relations; education; multiculturalism

\section{Un “templo de luz": Frente Negra Brasileña (1931- 1937) y la cuestión de la educación \\ El artículo examina como la Frente Negra Brasileña (1931-1937) - considerada la mayor y la más}

importante organización negra que se ha proyectado en el escenario nacional después de la abolición de la esclavitud - discutió, problematizó y trató la cuestión de la educación. Se comprueba como las lideranzas de esa organización tenían una visión crítica en relación a la falta de políticas públicas destinadas a la populación negra y concebían la educación como una herramienta estratégica para la inserción de ese segmento popular a la sociedad. Además de la integración social, la educación posibilitaría la eliminación de los perjuicios y, en última instancia, garantiría las condiciones para el ejercicio da la plena ciudadanía.

Palabras clave: negros; relaciones raciales, educación; multiculturalismo

Thais Nivia de Lima e Fonseca

Instrução e assistência na capitania de Minas Gerais: das ações das câmaras às escolas para meninos pobres (1750-1814)

Neste artigo, pretende-se discutir as relações entre a função civilizadora da instrução e de seu papel assistencial pelo estudo das ações das câmaras e de instituições pias para a educação de meninos pobres. No Antigo Regime, a educação para as camadas mais baixas da população associava-se à difusão da doutrina cristã e à formação profissional como meios de controle e era realizada em instituições assistencialistas. O ensino das primeiras letras visava facilitar o aprendizado da doutrina, sem criar possibilidades de ascensão social pela educação. Sobressaía a solução da educação profissional, do aprendizado de ofícios que pudessem servir de ocupação e de sustento. A legislação portuguesa definia os destinos a serem dados aos órfãos, e a educação que lhes seria destinada deveria ser compatível com seu nível social de origem. Na América 